\title{
7
}

\section{Narration at the Postcolonial Moment: History and Representation in Abeng}

\begin{abstract}
Being woman and Antillean is a destiny difficult to untangle. ... The Antilles is my natural mother and it is with her that I have accounts to settle, like any daughter with her mother, before becoming completely an adult.
\end{abstract}

-Maryse Condé

With modernization everything has to be recoded, for now people are on the move away from home territories and genealogies.

By the time Caribbean literature became a major player in the cultural politics of postcolonialism and postmodernism in the 1980s, the claim that modernity and modernization could lead to a unity of experience, a synthesis of culture, and a unified language of the nation in the formerly colonized spaces was being rigorously questioned. Indeed, after two decades of political independence and economic and cultural dependence, and the increasing influence of modern EuroAmerican discursive practices such as television and film, few people were certain that decolonization constituted a radical disconnection from the European modernist narrative initiated by Columbus and sustained by colonialism. Moreover, if Caribbean discourse during the period of decolonization appropriated the narrative strategies of high modernism to resist an ecumenical European notion of history which imprisoned the Caribbean subject in the realm of the "other" and its 
economy of representation, in the period after independence it was becoming clear that attempts to appropriate and revise the European language and its topoi were already a mixed blessing. Modernist forms could allow the Caribbean writer to "derealize" and decenter colonial systems of meaning, and even deconstruct the totalizing claims of European history, but the resulting narratives were still imprisoned in the colonial language and its phallocentric privilege. ${ }^{1}$

In an attempt to break out of the ideologies that had continued to sustain systems of domination even after independence, a new generation of Caribbean women writers, such as Michelle Cliff and Erna Brodber, has emerged to reopen the debate on history, representation, and identity initiated by their precursors. This generation of writers also seeks to revise the terms by which we read the West Indian experience and to interrogate the idealized narrative of the nation which values synthesis over hybridity in cultural formation and totality over diversity in history. These writers are not merely calling modernist notions of history and representation into question; they are also insisting on the need for what Stephen Slemon calls "an identity granted not in terms of the colonial power, but in terms of themselves." 2 And as Rhonda Cobham has noted in a review of recent novels by Caribbean women writers, instead of affirming a history of connections and linear genealogies, these writers use "the techniques of postmodern writing to reconstruct rather than deconstruct a postcolonial history." 3

At the heart of Cobham's comment is an oxymoron that is the key to understanding recent Caribbean writing and the status of the modernist project in the region: on one hand, the well-known techniques of postmodernism-temporal fragmentation, parody, intertextuality, and repetition-are being used by these writers to subvert institutionalized history; but, on the other hand, these writers are striving to establish an authoritative Caribbean narrative of history. Whereas contemporary Western novelists have acquiesced to Jean-François Lyotard's definition of the postmodern "as incredulity toward metanarratives," and have even succumbed to the premise that the great

1. I use "phallocentric privilege" in the way it has been articulated by Lemuel A. Johnson in "A-beng: (Re)calling the Body In(To) Question," in Out of the Kumbla: Caribbean Women and Literature, ed. Carole Boyce Davies and Elaine Savory Fido (Trenton: Africa World Press, 1990), p. 131.

2. Stephen Slemon, "Waiting for the Post: Modernity, Colonization, and Writing," Ariel: A Review of International English Literature 20 (October 1989), p. 6.

3. Rhonda Cobham, "Women of the Islands," The Women's Review of Books 7 (July 1990), 31. 
narrative function is "losing its functors, its great hero, its great dangers, its great voyages, its great goal," many Caribbean writers seem to use postmodern narrative techniques to affirm the continuing urgency of an oppositional history and discourse that strive for the status of a grand narrative. ${ }^{4}$ Indeed, for writers such as Cliff the narrative of history in the Caribbean is legitimized by the writer's appeal to a repressed Afro-Caribbean historical consciousness, an erased hermeneutics of meaning, and a decentered subjectivity:

To write as a complete Caribbean woman, or man for that matter, demands of us retracing the African part of ourselves, reclaiming as our own, and as our subject, a history sunk under the sea, or scattered as potash in the canefields, or gone to bush, or trapped in a class system notable for its rigidity and absolute color stratification. It means finding the artforms of these of our ancestors and speaking in the patois forbidden us. ${ }^{5}$

As we will see in the close reading of Abeng which follows, Cliff's first novel is concerned with the deconstruction of the Eurocentric phenomenon in Jamaica as a prelude to unearthing the repressed Afro-Caribbean experience in the island. Thus the reconstruction of elided black identities and African fragments long lost in the colonial archive is as urgent as the deconstruction of modernism and modernity. For Marlene Nourbese Philip, a new writer from Tobago, it is imperative that the narratives of her generation of Caribbean writers "begin to recreate our histories and our myths, as well as integrate the most painful of experiences-loss of our history and word."6 Thus history, conceived doubly as what Lemuel Johnson considers a threat and a condition of possibility, revolving around dominant presences as much as forgotten or negated absences, "summons up a relevant genealogy of disconnections and connections." 7 The central question now is this: what form and language does this history of connections and disconnections take as it strives to represent loss and to affirm an Afro-Caribbean presence? In what ways is Davies and Fido's "reality of absence, of voicelessness, of marginalization" in the lives of Carib-

4. Jean-François Lyotard, The Postmodern Condition: A Report on Knowledge, trans. Geoff Bennington and Brian Massumi (Minneapolis: University of Minnesota Press, 1984), p. xxiv.

5. Michelle Cliff, "A Journey into Speech," in The Land of Look Behind: Prose and Poetry (Ithaca,

N.Y.: Firebrand Books, 1985), pp. 14-15.

6. Marlene Nourbese Philip, "The Absence of Writing or How I Almost Became a Spy," in Davies and Fido, Out of the Kumbla, p. 278.

7. Johnson, p. 112. 
bean women linked "to the necessity to find a form, a mode of expression" that deconstructs both the ideological machine of imperialism and phallocentricism?8

The uniqueness of Cliff's aesthetics lies in her realization that the fragmentation, silence, and repression that mark the life of the Caribbean subject under colonialism must be confronted not only as a problem to be overcome but also as a condition of possibility-as a license to dissimulate and to affirm difference-in which an identity is created out of the chaotic colonial and postcolonial history. In writing about the ways in which Caribbean subjects strive to subjectify themselves within the commodified space and time of colonial modernity, Cliff finds discursive value in the very fragmentation that other commentators have seen as the curse of West Indian history. According to Cliff, fragmentation can indeed function as a strategy of identity since the colonized writer struggles "to get wholeness from fragmentation while working within fragmentation, producing work which may find its strength in its depiction of fragmentation, through form as well as content." 9 Although the goal of narrative is to overcome it, fragmentation also enables writing in three main respects: First, it allows the writer to recover the colonial repressed without resorting to what François Lionnet aptly calls "the ancient symmetry and dichotomies that have governed the ground and the very condition of possibility of thought, of 'clarity,' in all Western philosophy." 10 Second, it enables the writer to inscribe herself in the previously disdained vernacular and to use it to challenge the norms of the "Queen's" English. And finally, it helps her undermine the authority of given discourse through intertextual references and parodic forms that question the historical totalities that sustain ethnocentrism.

In the first instance, an archeological quest for Caribbean beginnings outside the framework of official history is imperative. Writing squarely within the tradition of the nouveau roman, Cliff posits narrative as a process in which history has value not because of its teleological claims, but because of its discontinuity, its concern with blanks, ruptures, and interruptions. Moreover, the manifest discourse of colonialism is important only in its contrastive relationship to the un-

8. Carole Boyce Davies and Elaine Savory Fido, "Introduction: Women and Literature in the Caribbean: An Overview," in Out of the Kumbla, p. 4.

9. Cliff, "A Journey into Speech," pp. 14-15.

10. Françoise Lionnet, Autobiographical Voices: Race, Gender, Self-Portraiture (Ithaca: Cornell University Press, 1989), p. 6. 
spoken history of the African subaltern in the Caribbean. Second, the recovery of a patois and the recentering of the oral tradition in cultures in which written forms have been hegemonic is a precondition for what Johnson calls the speaking of the New World female presence. ${ }^{11}$

In relation to colonial discourse, the kind of historical knowledge yielded by the narrative of decolonization appears incomplete because of its failure to develop forms that give voice and presence to the unspoken and unwritten discourse of the dominated. The question that arises from this incompleteness is common in women's narratives in other cultures and has been raised succinctly by Françoise Gaillard in another context: "How to write History when historical reality seems to come apart and can no longer be experienced except as a collection of non-totalizable anecdotes." 12 Instead of seeking to establish a unique Caribbean narrative of history, as some of the writers discussed in previous chapters try very hard to do, Cliff seeks to write what amounts to a schizophrenic text, one in which subjects realize their knowledge through their "split consciousness" and their suspension in a void between official language and the patois. Her narrative impetus here is the belief that "it would be as dishonest to write the novel entirely in patois as to write entirely in the King's English. Neither is the novel a linear construction; its subject is the political upheavals of the past twenty years. Therefore I have mixed time and incident and space and character and also form to try to mirror the historical turbulence."13

Through deliberate strategies of intertextuality, Cliff reifies the linguistic and ideological conflicts that arise when colonialist discourse is challenged by the vernacular, when official versions of history are questioned by the silent history of the poor and powerless. By establishing the antagonistic relationship between linguistic forms (especially the oral and the written), and through the interpolation of time frames and the spatialization of historical events, she represents both the value and limits of fragmentation as a condition of history and as a strategy of representation. Furthermore, as a narrative of turbulence and crisis, Abeng is not intended simply to evoke the value of otherness, but also to provide a genealogy of the loss of value and speech in the colonial subject. By dispersing the historical narratives of colonial-

11. Johnson, p. 119.

12. Francoise Gaillard, "An Unspeakable (Hi)story," Yale French Studies 59 (1980), 137.

13. Cliff, "A Journey into Speech," p. 14. 
ism, Cliff recenters, and gives value, to margins and edges. ${ }^{14} \mathrm{My}$ intention in this chapter is to show that as a narrative whose goal is to disorient the reader from entrenched forms of modernism, Abeng finds its power in its parasitic and subversive relationship to previous texts, which it appropriates and then spits out, clearing a space for alternative systems of representation.

\section{Intertextuality and the Journey into Speech}

First, the question of intertextuality. In a powerful conceptual study of intertextuality in narrative, Lauren Jenny has asserted that "without intertextuality, a literary work would simply be unintelligible, like speech in a language one has not yet learned. We grasp the meaning and structure of a literary work only through its relation to archetypes which are themselves abstracted from long series of texts of which they are, so to speak, invariants." 15 As we have already seen, Cliff's works arise from the author's consciousness of her troubled relationship with her colonial heritage and its language, and from her dissatisfaction with Caribbean male discourses on national identity. The centering of strategies of intertextuality in Abeng is the clearest evidence of Cliff's determination to establish a narrative that, by evoking the disjointed forms of experience which define the colonial and postcolonial subject, posits new ways of reading West Indian identity and experience.

In this regard, the relation of Cliff's text to other texts is not only a way of decentering the Western narrative and the colonial library from its dominant position in the Caribbean mind, but also a means of deconstructing or reconstituting modernist themes and categories first raised in the works of her precursors. Indeed, intertextuality is Cliff's way of positioning her narrative within an archive defined by the opposed claims of Africa and Europe in the Caribbean episteme; intertextual reference becomes a method of interrogating the foundational status of African and European cultures. This kind of intertextuality, as Linda Hutcheon has observed in her study of form in contemporary fiction, "simultaneously works to affirm-textually and hermeneuti-

14. See Linda Hutcheon in A Poetics of Postmodernism: History, Theory, Fiction (New York: Routledge, 1988), p. 130.

15. Lauren Jenny, "The Strategy of Form," in French Literary Theory Today, ed. Tzvetan Todorov, trans. R. Carter (Cambridge: Cambridge University Press, 1982), p. 34. 
cally-the connection with the past" and to situate a text in the world "of discourse, the 'world' of texts and intertexts."16 However, Cliff's (textual) psychoanalysis of the past is modernist in one major respect-its orientation toward a future in which the Caribbean crisis of identity will be resolved.

In any case, intertextuality in Abeng allows the narrator to present the reader with a dual mediation of the Caribbean experience; the text echoes, revises, and sometimes amplifies both colonial discourse and its more immediate anticolonial precursors. Our reading of Cliff's novel is thus conditioned and predetermined by our awareness of its relationship to other Caribbean texts; the text constantly reminds us that we have no access to the history of the islands except through the diverse forms of discursive practices which have previously represented it. To borrow Michel Foucault's phraseology, the frontiers of the text are never clear-cut: "Beyond the title, the first lines, and the last full-stop, beyond its internal configuration and its autonomous form, it is caught up in a system of references to other books, other texts, other sentences: it is a node within a network." 17

As we shall see later in this chapter, Cliff's priority is not the "objective" status of Caribbean history, although this is by no means an unimportant point in her concerns, but how this history is mediated by other texts and the discursive form this history takes. In all cases, her textual reflection on Caribbean historiography is highly paradoxical and informed by various kinds of doubleness. Indeed, the title of the novel foregrounds the doubleness of the Caribbean experience and the ways it is represented: we are informed that abeng is an African word for "conch shell," but the word has been adjusted and transformed by its function in the New World beyond its original meaning and intention. While a conch shell in Africa may be an agent of sound, speech, and the inner experiences of self, in the Caribbean it has become a mark of both displacement (calling the slaves to the canefields) and resistance (passing the messages of Maroon armies). For this reason, the conch shell is a sign of both the narrator's connection to her previously repressed African past and her functional distance from it; it is a symbolic representation of the process of historical remembering and dismembering. ${ }^{18}$

Even before we start reading the text itself, Cliff suggests several

16. Hutcheon, p. 125.

17. Quoted in Hutcheon, p. 127.

18. Johnson, p. 113. 
ways in which the desire for an alternative history of the Caribbean is predicated on the narrating self's awareness of its placement in a state of cultural limbo and doubleness. This point is underscored in the author's acknowledgment of her literary influences, in her dedication, and in the opening epigraphs. Her indebtedness is to folklorists and scholars involved in the archeological quest for the repressed African tradition in the Caribbean, and to feminist writers involved in the establishment of a women's literary tradition. ${ }^{19}$ Although Abeng is a work of fiction, it is already implicated in other, social and historical discourses which it seeks to elaborate or contextualize. In this process of elaboration and contextualization, as Johnson has noted, the author asserts her "recognition of resistance and of the self-dissolving threat that history can be." 20 In addition, Cliff dedicates the book to two authors whose texts are generated by a loss of place and genealogy: both Jean Toomer and Bessie Head wrote about a mulatto angst that represented their suspension between the white and black traditions that had socially determined them, but that they could not wholly embrace. This sentiment of loss and displacement is further enhanced by Cliff's epigraphic use of a poem by Basil McFarlane in which birth and death are encased in the same emotional and temporal frame. Both are evoked through a self-conscious elegiac tone that calls attention to the state of poetic abandonment which many colonial and postcolonial writers, especially those in exile, share. ${ }^{21}$

But if McFarlane's poem-and the slave lament that follows itstress the moment of loss and displacement, a second form of intertextuality connects Cliff to a reconstructive and intransitive tradition of Caribbean writing. Indeed, we cannot read Abeng without hearing the echoes of other Caribbean texts. For example, the first paragraph of the novel ("The island rose and sank. Twice. During periods in which history was recorded by indentations on rock and shell" [p. 3]) provides the reader with a geological evocation of Caribbean beginnings which also echoes a famous line from Edward Brathwaite's "Islands

\footnotetext{
19. The "network" of references in which Cliff "operates" is suggested in the acknowledgments on the copyright page of Abeng (Trumansburg, N.Y.: Crossing Press, 1984): for "some of the details" of her book, Cliff says she is indebted to other books and works (those of Zora Neale Hurston, Jervis Anderson, and Orlando Patterson), folksingers (Olive Lewin and her group), and leading feminists such as Audre Lorde and Adrienne Rich. Further references are in the text.

20. Johnson, p. 125.

21. For the poetics of loss and exile in postcolonial literature, see Edward Said, "Reflections on Exile," Granta 13 (Autumn 1984), 157-72.
} 
and Exiles" - "The stone had skidded arc'd and bloomed into islands." 22 Similarly, the line that opens the second paragraph- "This is a book about the time which followed on that time"(p. 3)-echoes notions of "before time" first raised in Zee Edgell's Beka Lamb.

An even more direct and dramatic example of intertextual reference is the episode surrounding the slaughter of a pig at the middle of the novel: the eating of the pig's "privates" signifies Clare's exclusion from patriarchal rituals (p. 57), but it is also important because of the way it calls to mind the famous killing of a pig in Marshall's The Chosen Place, the Timeless People, an incident that signalizes Saul's alienation from the world of the Caribbean peasantry. Marshall's influence on Cliff is also apparent in the latter's representation of the tension between AfroAmericans and Caribbean blacks (p. 86), which brings to mind the struggle of the Bajans in Brown Girl, Brownstones to distinguish themselves from native American blacks. Another important intertextual reference is Mr. Powell's experiences in New York during the Harlem Renaissance and his acquaintance with Zora Neale Hurston (pp. 8687 ). In this example, a fictional character connects us to writers and texts in the African diaspora.

No doubt many other examples can be found, but they all serve a clearly defined theoretical function: they constitute what Jenny calls a "super-parole" and show how "intertextuality speaks a language whose vocabulary is the sum of all existing texts." 23 Within the context of Caribbean modernism and its discourse, Cliff's evocation of other black texts is a radical means of expanding the Caribbean social and semantic space while decentering the colonial tradition; her referents are no longer determined solely by the colonial library, and her primary references are no longer Eurocentric. Intertextual echoes are also important because of their powers of negation. This feature is particularly pronounced in Cliff's use of parody, a textual strategy thatin modern fiction as a whole-allows the author to "enshrine the past and to question it." 24 The past is enshrined because it is an inescapable part of the Caribbean experience which cannot be wished away or written out of existence; but it is questioned because it is an instrument of European power and domination. In effect, Cliff's mode of narration, as I show in greater detail below, is shaped by the doubleness of

22. See Edward Brathwaite, The Arrivants: A New World Trilogy (London: Oxford University Press, 1973), p. 48.

23. Jenny, p. 45.

24. Hutcheon, p. 126. 
Caribbean history itself - the need to simultaneously represent dominant discourse, its referent, figures, and spectacles, and to question its privileges; the desire to psychoanalyze the trauma of history but also to transcend it.

Consider, for example, the following description of the queen as the emblem of imperial power in colonial Jamaica:

The portrait of the white queen hung in banks, department stores, grocery stores, schools, government buildings, and homes-from countryside shanties to the split-levels on the hills above Kingston Harbor. A rather plain little whitewoman decked in medals and other regaliawearing, of course, a crown. Our-lady-of-the-colonies. The whitest woman in the world. [P. 5]

Disjunction is an important strategy of narration here: the queen, the symbol of imperial power and the supplement for a white mythology whose authority is derived from the relationship between sign and signifier, is displaced within the very portrait that signifies her power. ${ }^{25}$ The description proceeds to foreground the obviously metonymic displacement of the picture and the plain woman it represents and to raise troublesome questions about the value of this signifier: Does the plain white woman have a presence outside her medals and the crown? Without these symbols of power, isn't she just another white woman? Of course, you cannot have one without the other: the queen is the whitest woman in the world not because of anything inherent in her character, but because of her symbolic presence in the relations of power and domination which define Jamaica as a British colony. Indeed, the narrator's description of the queen as "our-lady-ofthe-colonies" emphasizes the ecumenical nature of her power. However, the narrative counters this power through a parodic tone that reduces the whitest woman in the world to the object of la bêtise.

Here Cliff's primary narrative strategy is to call attention to the symbolic representation of white mythology and, at the same time, to open a space in which this mythology can be reversed or subverted by a counter-discourse built on narrative algebraization and understatement. In official discourse, as in the case of the Jamaican currency, a binary relationship-rather than an opposition-between the native and the colonizer has been instituted to stabilize the existing system of

25. See Jacques Derrida, Margins of Philosophy, trans. Alan Bass (Chicago: University of Chicago Press, 1982), p. 213. 
domination. Apart from being a form of exchange, the currency is a symbolon in which the extinct Arawak is supposed to have equal value with the "sovereign crest." In Cliff's (re)presentation of this symbolon, however, the opposite effect is underscored as the narrative scrutinizes the absent Arawak and his or her relationship to the dominant: "Jamaican money bore the word JAMAICA, and the sovereign crest of the island-an Arawak and a white conqueror: only one of these existed in 1958" (p. 5). Thus the colonizer's cultural text (the currency) is represented and dispersed at the same time; it is shown to have achieved coherence or totality at the expense of the other, who now exists only as a sign with no referent.

My contention here is that Cliff's narrative derives its power from its capacity to expose the contradictions within the colonizer's economy of representation. Because the dominant social text derives its authority from its monotheist ideology, Cliff's text uses a devastating plurality to expose what the monological text represses; official or dominant enunciation is shown to have a double or uncanny element that contests its claim to ideological absoluteness or control. Also, the value of Abeng, as a self-consciously revisionist text, does not lie solely in what it exhibits, but also in the absent or unspoken aspects of the Caribbean experience which it uncovers from under official rhetoric. Cliff foregrounds the ways in which interrogating, or even digging up, the past resurrects meanings that both mock and haunt the dominant culture in her portrait of the Parish Church, the very embodiment of white power in Jamaica, and the deep historical secret it represses:

The Parish Church was High Anglican-it was the church of attendance of the white governor, and members of the royal family stopped there when the queen's yacth, H.M.S. Britannica, docked in Kingston harbor. . . . In 1958, while digging near the churchyard during some renovations to the building, workers uncovered a coffin of heavy metal-a coffin of huge proportions. . . A brass plate which had been affixed to the coffin and etched with an inscription informed the vicar that the coffin contained the remains of a hundred plague victims, part of a shipload of slaves from the Gold Coast, who contracted the plague from the rats on the vessel which brought them to Jamaica. [P. 7]

Witness the contrast between the church's self-representation as a continuation of European high culture and the abysmal slave history on which colonial society is founded. Although the narrator does not make this connection explicitly, the text suggests that the history of 
Jamaica will remain half-known unless one fragment is viewed in relation to the other; the meaning of Caribbean history arises from the tense conjunction between manifest and celebrated Eurocentric meanings and a repressed Afro-Caribbean hermeneutics.

But it is when we turn to Cliff's engagement with historiography that we begin to realize that her concern with the representation of history is also part of a theoretical enterprise to rescue "Caribbean facts" from their subordination to the European sense of history as a totality with a privileged telos. Because historiography is such an important and contentious issue in Cliff's text, we can in fact read Abeng as a metafictional text. This is the kind of text which, according to Hutcheon, goes beyond a preoccupation with the nightmare of history and

\begin{abstract}
puts into question, at the same time as it exploits, the grounding of historical knowledge in the past real. ... It can often enact the problematic nature of the relation of writing history to narrativization and, thus, to fictionalization, thereby raising . . . questions about the cognitive status of historical knowledge. ... What is the ontological nature of historical documents? Are they the stand-in for the past? What is meant-in ideological terms-by our "natural" understanding of historical explanation? ${ }^{26}$
\end{abstract}

Let us suspend the question of the relationship between historiography and narrativity for the time being and concentrate on Cliff's examination of the nature of historical knowledge and the representation of history. At the beginning of the book, the whole question of the writing and recording of history is shown to be contested and determined by power relations and opposed desires in Jamaica. The narrator begins her quest for historical forms by tracing her "record" of history to geological formations, to periods when history was "recorded by indentations on rock and shell" (p. 3). This geological genesis of the Caribbean is important because it negates traditional histories, which posit the "discovery" as the ground zero of the Caribbean experience; at the same time, the archeologizing gesture raises the possibility that there are modes of historical knowledge which are accessible to us outside previously privileged European documents. Thus Cliff adopts what we may call an annales approach to history in which rocks, eye-witness accounts, coffins, and oral forms have as

26. Hutcheon, pp. 92-93.

242 
much authority as documents: the coffin buried under the Parish Church (p. 7), the trilobite fossil Clare discovers on the beach (p. 8), her grandmother's cut-glass pitcher (p. 13), the elm trees on the family's lost plantation (p. 23), and the "CASTRO SI, BATISTA NO" sign on the wall of the church (p. 22) are all important marks of history. They represent different (if not alternative) means of making sense of the past; they are part of the museum from which the desire of history rises. ${ }^{27}$

It is one thing, however, to represent the fragments of the museum and record the dispersed facts of history; it is quite another to get into this history and recover its cognitive value through the creation of narrative. Clare faces this problem often in the novel. In her visit to Paradise Plantation, for example, she can clearly see the various elements that illustrate her family history, but how can she relate these fragments to each other when things seem to float and "the background could slide so easily into the foreground" (p. 25)? Indeed, what is the foreground and what is its background? How is historical value established? The truth is, "signs of a former life" do not naturally give that life meaning or significance; Clare will clearly see the traces of the slaves' cabins on the earth every time she visits the old family plantation, but this is no guarantee that she will know and understand "the former life they represented" (p. 25; also pp. 26 and 27). The signs of history cannot be mastered because the subject lacks a context and theory for establishing connections between what appear to be the dispersed and contradictory signs of West Indian history and the totalized (and sanitized) colonial version taught in school. An easy way out, it of ten appears to Clare, is to let desire and the imaginary become substitutes for historical signs: "She sometimes imagined that the walls of certain places were the records of those places-the events which happened there" (p. 32). Rather than seeing historical markers as signals of something else, Clare wants to invest value in these signs themselves; and when she is disappointed by historical artifacts that don't cohere with her desires, she prefers escaping from history altogether (pp. 36-37).

Why does Clare have such difficulties understanding history even when its signs are easily available to her? The simplest answer to this question is that the context in which she tries to master historical discourse, and her training and experience about the value of the

27. See Gaillard, pp. 147-48. 
historical artifact, already negate the significance of forgotten or repressed histories. Boy Savage has created in his daughter a sense that history has no cognitive status unless it is informed by a vision of myth and natural disaster: "Nothing, to him, was ever what it seemed to be. Nothing was an achievement of human labor" (p. 9). The father's dystopian view of history disables Clare's archeological quest as do her mother's romantic vision of Jamaica (p. 50) and the textbook histories of Jamaica which have repressed the experiences of those who resisted the official order. But there is another, more significant, reason why Clare is inevitably disabled in her attempts to recover her history-she does not know how to master historical discourse because she has no narrative authority that might enable her to capture a fragmented history in writing. In other words, she cannot combine her meanings to reconstruct the whole.

Gaillard has made an important theoretical proposition regarding selfhood and the writing of fragmented histories which coheres with Cliff's conceptualization of writing "whole" within the fragmentary. According to Gaillard, if the identity of the subject of a narrative cannot be established, then character "is no longer the appropriate place for the performance of that totalization of meanings which goes beyond apparent contradictions. . . . Since character, now that it is itself divided, cannot synthesize an experience fragmented anyway in other respects, its intervention provides no hope of carrying out the syntactical integration of discursive odds and ends which is known as historical narrative." 28 How then does one write a historical novel predicated on a schizophrenic and divided subject? For Cliff, discourse and narrative must take the place normally reserved for character in fiction, and the tension between language and speech must also be valorized to expose the conditions that have erased the identity of the colonized subject.

\section{The Collapse of the "Given"}

As we have seen in previous chapters, the struggle between language and speech in the Caribbean text is symptomatic of two radically opposed systems of representation-the oral discourses of the peasantry and the written texts promoted by the colonial school. Clare

28. Gaillard, pp. 147-49. 
Savage strives to develop her identity between the two, but because she cannot establish a fundamental relationship with either (she does not share her mother's deep passion for the folk, and her belief in official versions of history is steadily undermined in the course of the narrative), the text raises the possibility of a third discourse that is irreducible to either language or speech. In many instances, this third discourse is posited in the gap between the folk and official versions of history. Thus although Nanny-"the sorceress, the obeah woman" (p. 14) - and her slave revolt are absent from the colonial textbook, we are never made to believe that it is enough for the narrative to recover this repressed history and to affirm it in writing. Indeed, what strikes us about the woman warrior is not the reality of her existence, which cannot be doubted-“"There is absolutely no doubt that she actually existed" (p. 14) - but the fact that in spite of historical signs that testify to her existence (ruins, for example), Nanny has not been admitted into Jamaican official history. The narrator's priority is not to prove that Nanny actually existed, but to show how her presence is negated in official versions of history because she threatens Jamaica's foundational narrative, which would prefer to trace its sources to Europe rather than Africa.

Furthermore, the narrator's almost casual reproduction of Nanny and her legends allows Cliff to emphasize one of her most consistent themes in the novel: our familiarity with the surface language of history does not allow us to escape its ruse; history evades, or is foreclosed from, even those who make it. Thus although the people in the Tabernacle church "could trace their bloodlines back to a past of slavery . . . this was not something they talked about much, or knew much about" (p. 18). The narrator's theme, then, is not the power and majesty of history, or even its eroticism, but how it eludes our knowledge or cognition. In many cases the narrative emphasizes how history is scattered around its subjects and how they relive their past without grasping its significance: "They did not know that their name for papaya-pawpaw-was the name of one of the languages of Dahomey" (p. 20); "Some of them were called Nanny, because they cared for the children of other women, but they did not know who Nanny had been" (p. 21). Again, we can see how the narrator makes historical discourse problematic by exposing her subjects' inabilities to confer ideological value on the signs embedded in their speech.

In the same vein, Cliff indicts official discourse for contributing to the interpretative failure of the colonial subject as it seeks to historicize 
its experiences: although the school and the government circulate "information" and "facts" intended to further the natives' knowledge of Jamaica's history, ordinary people find their significant experiences buried in discursive acts that alienate them. For example, color and caste are key codes in explaining social relationships in colonial Jamaica, but in Clare's school, "as in the rest of society, it was concealed behind euphemisms of talent, looks, aptitude" (p. 100). If official discourse conceals through evasion, then the author seeks a counterdiscourse that penetrates the illusions sustained by such evasions to effect a postcolonial discursive practice.

But if modernity-as a project of the Enlightenment-derives its authority from its absolutist character, as Ernesto Laclau has argued in an essay on contemporary social theory, it can only be weakened from "an analytic terrain from whose standpoint this weakening is thinkable and definable." This terrain is "neither arbitrary nor freely accessible to the imagination, but on the contrary it is the historical sedimentation of a set of traditions whose common denominator is the collapse of the immediacy of the given." 29 In seeking the imaginary collapse of the given, Cliff resorts to wide-ranging discursive strategies: these include constant authorial intrusions into the narrative, commentary on the significance of certain words or expressions, and even the "unmediated" reproduction of discourses from other sources, such as an editorial from the Daily Gleaner (p. 4). In all these cases, the narrative calls attention to the possibilities of alternative meanings by enhancing its own plurality.

For example, at the beginning of the novel the Daily Gleaner, the official organ of the Jamaican ruling class, declares the 1958 mango season to have produced the "biggest crop in recent memory"; but almost immediately this "given" is shown to be determined by the paper's need to promote a certain image of Jamaica: "The paper ran an editorial which spoke of God's Gift to Jamaica, and concluded by telling all inhabitants to be hospitable to tourists" (p. 4). The editorial necessity to assert the "given" fact points to the Achilles' heel of official discourse-what it assumes to be collective or absolutist meanings are indeed disputed by other sectors of the society. Thus while the newspaper editorial portrays the mango as Jamaica's gift to the world and a tourist attraction, for most island people living in the United States

29. ErnestoLaclau, "Politics and the Limits of Modernity," in Universal Abandon? The Politics of Postmodernism, ed. Andrew Ross (Minneapolis: University of Minnesota Press, 1989), p. 67. 
and England, "the mango was to be kept an island secret," not to be displayed in foreign stores and markets (p. 4). These contrasting images of a national symbol are excellent examples of Cliff's determination to devalorize the given by exposing its plural meanings. Her narrative constantly reminds us that if we read history from an absolute perspective, as the Enlightenment modernists would like us to, then we will not understand the contradictory motives behind historical acts. For example, the colonial textbook represents the abolition of slavery as a benign act by the British government, but Cliff's narrative unearths and brings into play all the unacknowledged facts and interests involved in this historical event; in placing slavery in its proper context, "it is important to take it all in, the disconnections and the connections, in order to understand the limits of the abolition of slavery" (p. 28).

Moreover, to weaken the given field of discourse, a decolonized narrative of the kind Cliff proposes in Abeng begins with the premise that the facts and forms of history are not easily accessible to the imagination; we have to struggle even to distinguish the historical fact from figures of eroticism and colonial desire. This kind of struggle is prefigured in Clare's attempts to come to terms with the annihilation of Anne Frank: "Why did they kill her? That was a question whose answer was always out of reach. It was hard for Clare to imagine someone, another girl, who was of her age or near to her age, dyingto imagine her dying as Anne Frank died, in a place called BergenBelsen, the year before Clare was born, was impossible" (p. 68). Because Clare cannot transfer Anne Frank's experiences into her immediate universe, the Jewish girl's realities remain paradoxically knowable and inaccessible: although Anne had "left behind evidence of her life" (p. 69) in the form of her diary, this is no guarantee that we can have complete knowledge of her past, what she felt in her moment of annihilation, or the real motives of those who destroyed her.

Similarly, the life of Christopher Columbus is relived in countless documents and monuments, but what intrigues the narrator is the possibility that we may not know who the real Columbus was or what the motives were for his "discovery." Was he a Marano, a Sephardic Jew hiding his identity behind Christian worship? Was he a Jew in search of a homeland for his people in a New World diaspora (p. 67)? In Abeng, a historical event that is one of the foundations of modern Western history is almost casually called into question: "This man, whose journeys had such a profound effect on the history and imagi- 
nation of the western world, is a relatively mysterious figure in the records of western civilization" (p. 67). In the circumstances, all historical knowledge must be tentative and incomplete; historiographical fiction must be aware of its limitations-there are "so many veils to be lifted," "so many intertwinings to be unraveled" (p. 67).

Despite her awareness of the limitations of her project, Cliff strives to evoke an alternative history or different means of gaining access to repressed experiences. The narration of this history does not follow a linear, progressive scale, however. Indeed the meaning of the marginalized and erased Caribbean experience is not sought in an area of logic and consciousness; rather it asserts or commemorates itself in an arena of madness and fantasy. If European conquerors created "fantastic images to render the actual inhabitants harmless" (p. 78), writing from the margins involves inventing spectacles that alienate the colonizers in their own language and history. In this regard, to use Edward Said's words, discursive language "is like a repertory theatre that stages numerous spectacles." 30 In Cliff's text, Nanny, the Maroon heroine, enacts her history as a spectacle-catching the bullets of the oppressor between her buttocks, she renders them harmless (p. 14). As spectacle, the history of the repressed creates its own illusion of immediacy. As a form of maroonage, this history is "unruly, runaway"; beyond its "exact meaning," this history functions before our eyes, "fierce, wild, unbroken" (p. 20), testimony to an order of things outside the Western logos. To borrow Jean Pierre Vernant's theoretical formulation, the historical spectacle-as a form of commemorationrecovers memory and reconquers the past; history as celebrated by memory becomes "a deciphering of the invisible, a geography of the supernatural." 31

Here is the narrative recall of Nanny reconquering Jamaican space and genealogy:

Now her head is tied. Now braided. Strung with beads and cowrie shells. Now she is disguised as a chasseur. Now wrapped in a cloth shot through with gold. Now she stalks the Red Coats as they march toward her cave, where she spins her Akan chants into spells which stun her enemies. Calls on the goddess of the Ashanti forests. Remembers the battle formations of the Dahomey Amazons. [P. 19]

30. Edward Said, "An Ethics of Language," Diacritics (Summer 1974), p. 33.

31. Jean Pierre Vernant, Myth and Thought among the Greeks (London: Routledge, 1983), p. 80. 
Now, if we recall that Cliff has carefully described Nanny as "the sorceress," then this dramatization of history suggests that for the woman warrior to empower herself, she had to transgress temporal limitations; her spectacle generates the discourse of the possessed woman who has defied the white mythology; the excessive world of magic counters the sanitized version of history in the textbook, history "lost in romance" (p. 30).

But what is the lesson to be learned from Nanny's example? For subjects like Clare who find it difficult, if not impossible, to gain access to their history and to empower themselves within it, characters such as Nanny and Mad Hannah suggest the power of "magical" practicea semiotic site, free and indeterminate, which privileges the excluded through transgression. Clare seeks such powers of transgression, especially in her attempts to understand the extermination of the European Jews, but at every stage of her reading and rereading, she finds it difficult to figure out how such acts happened. Since her father has been the primary mediator of her historical experiences, he is posited as the barrier to understanding "because to understand would be to judge her father as capable of the acts which had formed and sustained the holocaust" (p. 75). Unable to draw parallels between the events in Europe and her more immediate colonial experiences, Clare is entrapped in the very modes of knowledge which have privileged her: "She was a colonized child, and she lived within certain parameterswhich clouded her judgment" (p. 77). Clare's inability to understand amid the connections and disconnections of her childhood is related to the multiplicity of historical and social factors which hamper all her attempts to establish her identity: race, class, color, sexual identity, and gender. But a key element in Cliff's narrative method is her portrayal of Clare as a schizophrenic who has failed to accede fully to the realm of speech and language.

Let me elaborate this assertion by turning to Fredric Jameson's discussion of the relationship between language and schizophrenia in psychoanalysis. In his reading of Lacan's theory of the breakdown of the relationship of signifiers in the schizophrenic experience, Jameson observes that any breakdown in temporal relationships is also an effect of language:

It is because language has a past and a future, because the sentence moves in time, that we can have what seems to us a concrete or lived 
experience of time. But since the schizophrenic does not know language articulation in that way, he or she does not have our experience of temporal continuity either, but is condemned to live a perpetual present with which the various moments of his or her past have little connection and for which there is no conceivable future on the horizon. In other words, schizophrenic experience is an experience of isolated, disconnected, discontinuous material signifiers which fail to link up into a coherent sequence. ${ }^{32}$

Cliff's use of a fragmented narrative is the most obvious example of the breakup of temporal relationships in Clare's world: the Savage family lives in a world of dispersed spaces and discontinuity. If Clare seems unable to connect her past to her present, as we have already seen, it is because her social spaces are indeed schizophrenic. For instance, the family church could ideally be read as a sign of a continuous religious and cultural tradition, but Clare worships in her mother's Pentecostal church, her father's Calvinist church, and her grandmother's "private" church. Each of these symbolic spaces makes certain demands on her; they also represent certain ideological systems in contestation and underscore the set of differences which marks her life. When Clare tries to overcome the differences and divisions that define her world, she finds that the only avenue for this form of transcendence is the imaginary; but the imaginary also distances her from the historical contexts she has tried so hard to master.

In her friendship with Zoe, the material signifiers of difference "become more and more of a background, which only rarely they stumbled across and had to confront" (p. 95), but this imaginary overcoming of differences is both tenuous and dangerous. It is described as a "make-believe": "They had a landscape which was wild and real and filled with places in which their imaginations could move" (p. 95). Outside this imaginary landscape, Clare is overwhelmed by her displacement, which is inscribed by realities she cannot control; her sense of disconnection is exacerbated by her failure to establish any transparent relationship between signifiers. In her school in Kingston, we are told, Clare is on scholarship because her father cannot keep up with the payments; yet she is treated differently from the darkerskinned scholarship girls. Her privileging is certainly due to color and class (p. 96), but because the power of these codes depends on their

32. Fredric Jameson, "Postmodernism and Consumer Society," in The Anti-Aesthetic: Essays on Postmodern Culture, ed. Hal Foster (Port Townsend, Wash.: Bay Press, 1983), p. 119. 
invisibility, they create confusion in the girl and deepen "part of the split within herself"' (p. 96).

In the end, Clare's sojourn in the colonial landscape proves Jameson's observation that the schizophrenic "does not know personal identity in our sense, since our feeling of identity depends on our sense of the persistence of the "I" and the "Me" over time." 33 In Clare's struggle for identity, Cliff takes us to the limits of colonial alienation: we are no longer dealing with colonial subjects who are defined solely in relation to the other, for the dialectic of master and slave has become ineffective. Moreover, although the colonial subjects discussed in the previous chapters were often defined in relation to the colonial other, they still had some recognition of themselves as colonial subjects, be it in a positive or negative sense. In contrast, Clare's sense of self is defined by absolute repression: she does not even have the capacity to analyze or explain to Zoe "what she felt about their given identities in this society, where they met and where they diverged" (p. 121).

When she "drops" the patois in her final conversation with Zoe, Clare seems to have judged "the distance between them as now unbridgeable" (p. 134). Unsure about the meaning of her "I," which is not even sustained by an illusion of its uniqueness, Clare has been reduced to a dead silence about her own dreams: "She was not ready to understand her dream. She had no idea that everyone we dream about we are" (p. 166). And so we have seen Caribbean fiction shift from a dramatization of the power of the self and the uniqueness of its utterance (in Beyond a Boundary, for example) to a moment of closure marked by silence and emptiness. But in the quest for a postcolonial discourse the silence and emptiness at the end of Cliff's novel are portentous for two reasons. First, the existence of a gap in language affirms the continuing need for a narrative form that will take into account the contradictory impulses of Caribbean culture which Clare discovers the moment she raises questions of identity and gender. Second, it is in the gaps, the silences, and the absences exposed by contending discourses that the underprivileged Caribbean subject will find and affirm its voice.

33. Jameson, p. 119. 